\title{
冷やしばめにより丸鋼を充填した円孔を有する 鋼板のひずみ性状と疲労強度
}

\author{
内田 大介 1 - 森 猛 2 \\ 1正会員 三井造船株式会社 鉄構・物流事業本部 管理部 \\ （干104-8439東京都中央区築地5-6-4） \\ E-mail:duchida@mes.co.jp \\ 2正会員 法政大学教授工学部 都市環境デザイン工学科 \\ ( ( $184-8584$ 東京都小金井市梶野町3-7-2) \\ E-mail:mori@hosei.ac.jp
}

\begin{abstract}
溶接きずを除去するために設けた円孔の補修や，製作過程で鋼板にあけた円孔をやむを得ず埋戻す場合 の一手法として，丸鋼を冷やしばめすることによる円孔の充填が考えられる. 本研究では冷やしばめされ た円孔を有する矩形鋼板のひずみ性状と疲労強度を明らかにすることを目的とし，モデル試験体のひずみ 測定試験，ひずみ解析と疲労試験を行った。また，その疲労強度を高力ボルトが締め付けられた円孔を有 する矩形鋼板の疲労強度と比較した。
\end{abstract}

Key Words : expansion fit, strain measurement, strain analysis, fatigue strength, circular hole

\section{1. はじめに}

鋼構造物において，溶接きずの除去のために設けた円 孔，あるいは製作過程で設けた円孔をやむを得ず埋め戻 寸場合には，溶接が用いられることも少なくない，溶接 により埋め戻した箇所のきずの有無については，非破壊 検査により確認することが可能であるが，材質の変化や 高い残留応力の発生が懸念される.

溶接を用いずに円孔を充填する方法として，鋼板厚と 同じ長さで，その径が円孔径よりも大きい丸鋼を冷やし ばめすることが考えられる。この方法では，冷やしばめ により導入された支圧力による応力伝達が期待でき, 支 圧力の存在下では丸鋼と鋼板が一体としての挙動を示す とともに，気密性も確保できるものと期待される.

冷やしばめを含め，力ばめ，焼きばめ等のしまりばめ は，古くから軸受けと軸の接合等，機械部品の加工に用 いられており，数多くの研究が行われている．例えば, はめあい時の応力を実験的に確認したもの ${ }^{1)}$ ，理論的に 考察したもの ${ }^{2}$, 表面あらさや真円度がはめあい圧力, 押抜き力, 接触部の静止摩擦係数に与える影響について

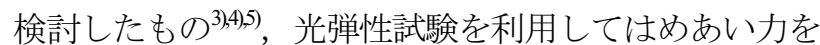
検討したものの,7，冷やしばめされたシャフトがボス部に 存在した亀裂に与える影響を検討したもの ${ }^{8)}$, 低温域の 線膨張係数を考慮した冷やしばめのしめしろの計算手法 の提案9), 孔を有するアルミニウム合金板にステンレス
ピン10)，あるいは鋼製ピン をカ11をばめした場合の疲労強 度に関する検討等がある、筆者らが調べた限り, 冷やし ばめを構造部材の断面欠損を充填する目的で適用し，外 力を受けた場合の応力・ひずみ性状や疲労強度に関する 検討を行った報告はない.

現在の機械加工精度や測定精度等を考慮すると，冷や しばめによる断面欠損充填を実構造に適用寸ることは困 難とも考えられる. しかし，機械加工技術や測定技術が 向上寸る可能性もあり, 試験室レベルとはいえ，その基 本的性状を確認寸ることは有益と考えられる.

本研究では，丸鋼が冷やしばめされた円孔を有する矩 形鋼板の応力・ひずみ性状と疲労強度を明らかにするこ とを目的とし，モデル試験体のひずみ測定試験，ひずみ 解析と疲労試験を行う。

\section{2. 試験体}

供試鋼材は板厚12mmのSM490YAである。鋼材の機械 的性質と化学成分を表-1に, 試験体の形状と寸法を図-1 に示す．試験体は，板厚 $12 \mathrm{~mm} の$ 矩形鋼板の中央に直径 23.0mmのドリル刃を用いてボール盤で円孔をあけたH試 験体と，H試験体の円孔に円孔径よりも径の大きい丸鋼

（S45C）を液体窒素で泠却してはめこんだR試験体の2 種類である. 冷しばめに用いる丸鋼は，その長さを鋼板 
表-1 供試鋼材の機械的性質と化学成分

\begin{tabular}{|c|c|c|c|c|c|c|c|c|c|}
\hline \multirow{2}{*}{ 鋼 種 } & \multicolumn{3}{|c|}{ 機械的性質 } & \multicolumn{4}{|c|}{ 化学成分 (\%) } & \multirow{2}{*}{ 備考 } \\
\cline { 2 - 8 } & $\begin{array}{c}\text { 降伏点 } \\
\left(\mathrm{N} / \mathrm{mm}^{2}\right)\end{array}$ & $\begin{array}{c}\text { 引張強さ } \\
\left(\mathrm{N} / \mathrm{mm}^{2}\right)\end{array}$ & $\begin{array}{c}\text { 伸び } \\
(\%)\end{array}$ & $\begin{array}{c}\mathrm{C} \\
\times 100\end{array}$ & $\begin{array}{c}\mathrm{Si} \\
\times 100\end{array}$ & $\begin{array}{c}\mathrm{Mn} \\
\times 100\end{array}$ & $\begin{array}{c}\mathrm{P} \\
\times 1000\end{array}$ & $\begin{array}{c}\mathrm{S} \\
\times 1000\end{array}$ & \\
\hline SM490YA & 398 & 534 & 25 & 17 & 32 & 133 & 18 & 3 & \\
\hline S45C & 345 以上 & 570 以上 & 20 以上 & $42-48$ & $15-35$ & $60-90$ & 3 以下 & 3.5 以下 & JIS規定値 \\
\hline
\end{tabular}

H試験体
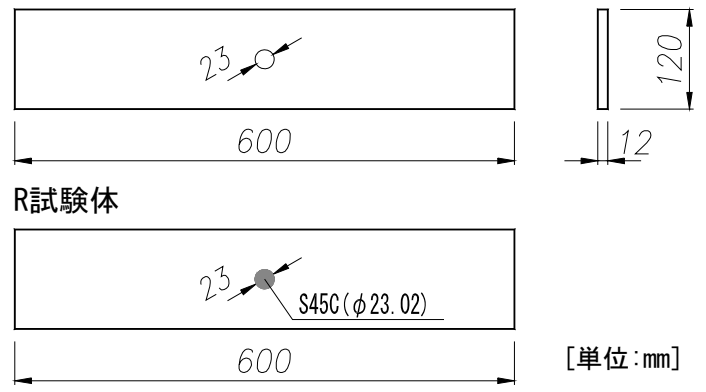

R試験体

図-1 試験体

表-2 試験体一覧

\begin{tabular}{|c|c|c|c|c|c|}
\hline 種別 & 試験体名 & $\begin{array}{l}\text { 円孔径 } \\
(\mathrm{mm})\end{array}$ & 丸鋼径 $(\mathrm{mm})$ & しめしろ $(\mathrm{mm})$ & 用途 \\
\hline \multirow{4}{*}{ H試験体 } & $\mathrm{H}-0$ & \multirow{11}{*}{$\begin{array}{r}23.00 \sim \\
23.021\end{array}$} & \multirow{4}{*}{-} & \multirow{4}{*}{-} & 静ひずみ測定 \\
\hline & $\mathrm{H}-1$ & & & & \\
\hline & $\mathrm{H}-2$ & & & & $\begin{array}{c}\text { 疲労試験 } \\
\text { 作, }\end{array}$ \\
\hline & $\mathrm{H}-3$ & & & & \\
\hline \multirow{7}{*}{ R試験仏 } & $\mathrm{R}-0$ & & $23.028 \sim 23.032$ & $0.007 \sim 0.032$ & 静ひずみ測定 \\
\hline & $\mathrm{R}-1$ & & $23.028 \sim 23.037$ & $0.007 \sim 0.037$ & \multirow{4}{*}{$\begin{array}{c}\text { 動ひずみ測定, } \\
\text { 疲労試験 }\end{array}$} \\
\hline & $\mathrm{R}-2$ & & $23.028 \sim 23.041$ & $0.007 \sim 0.041$ & \\
\hline & $\mathrm{R}-3$ & & $23.028 \sim 23.049$ & $0.014 \sim 0.049$ & \\
\hline & $\mathrm{R}-4$ & & $23.035 \sim 23.041$ & $0.014 \sim 0.041$ & \\
\hline & $\mathrm{R}-5$ & & $25.028 \sim 23.061$ & $0.007 \sim 0.061$ & \multirow{2}{*}{$\begin{array}{c}\text { なし } \\
\text { (冷やしばめ失敗 }\end{array}$} \\
\hline & $\mathrm{R}-6$ & & $23.035 \sim 23.044$ & $0.014 \sim 0.044$ & \\
\hline
\end{tabular}

の板厚と同じ12mmを目標として切断・加工した後，円 孔径+0.02mmを目標として端面加工用バイトで加工した。 加工した円孔と丸鋼の直径をマイクロメータを用いて対 称な4箇所で計測している. その結果から算出されたし めしろは0.007mm〜0.061 mmであった。 なお，丸鋼の表 面加工精度は，JIS B 0601-1982の仕上げ記号 $\nabla \nabla \nabla と し$ た.

冷やしばめは以下の手順で行った。 丸鋼とプライヤを 液体窒素に浸し，10分程度して気泡が出なくなったこと を確認した後に，まずプライヤを取り出し，そのプライ ヤで丸鋼を取り出した。そして，あらかじめ卓上ボール 盤の台に固定しておいた鋼板の円孔部へ丸鋼を運び，ド リルチャックを利用して丸鋼を円孔に押し込んだ。表-2 にここで用いた試験体とその用途を示す， R 試験体は7 体の製作を試みたが，しめしろが比較的大きい2体は冷 やしばめに失敗した。 R試験体の製作状況を写真-1に, 丸鋼充填部の一例を写真-2に示す.

\section{3. ひずみ測定試験}

丸鋼が冷やしばめされた円孔近傍のひずみを調べる目
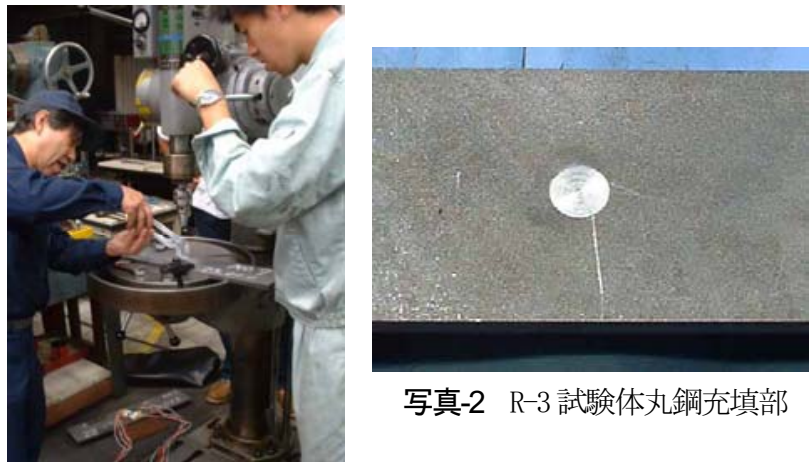

写真-2 R-3 試験体丸鋼充填部

写真-1 試験体製作状況

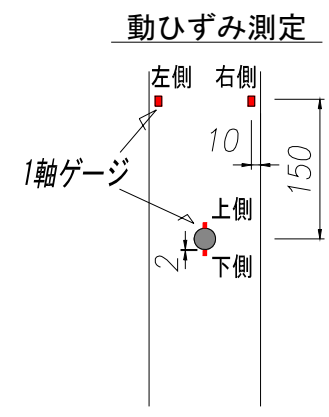

静ひずみ測定

図-2 ひずみゲージ貼付位置

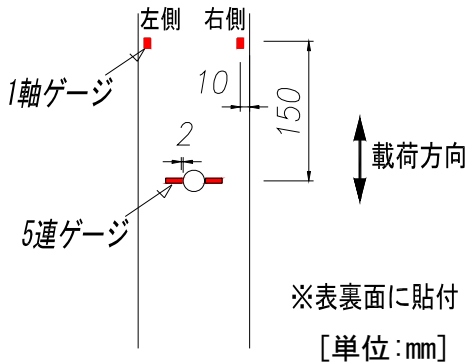

[単位: $\mathrm{mm}$ ]

的で，動ひずみ測定と静ひずみ測定を行った．荷重の方 向はいずれも試験体長手方向である。ひずみゲージの貼 付位置を図-2に示す。ひずみゲージは試験体の表裏面に 貼付している．1軸ひずみゲージのゲージレングスは円 孔近傍に貼付したもので $1 \mathrm{~mm}$ ，公称ひずみ（応力）測定 用に円孔から長手方向に $150 \mathrm{~mm}$ 離れた位置に貼付したも ので5mmである。また，静ひずみ測定に用いた5連ゲー ジの間隔は2mmであり，それらのゲージレングスは $1 \mathrm{~mm}$ である。

\section{(1) 動ひずみ測定試験}

動ひずみ測定試験では，R-1〜R-4試験体の4体を対象 とし，円孔端から試験体長手方向に $2 \mathrm{~mm}$ 離れた位置に貼 付した1軸ゲージの出力と荷重の関係から, 丸鋼部での 力の伝達状況を調べた. 繰返し荷重は，動的能力 $500 \mathrm{kN}$ の電気油圧サーボ式材料試験機を用い，後述の疲労試験 と同様に下限荷重を $10 \mathrm{kN}$ (公称応力 $6.9 \mathrm{~N} / \mathrm{mm}^{2}$ ) とし, 試 験体長手方向の公称応力範囲が $200 \mathrm{~N} / \mathrm{mm}^{2}$ （上限荷重 $298 \mathrm{kN})$ となるように与えた。繰返し速度は1Hz，荷重 とひずみのサンプリング速度は100Hzである.

図-3に動ひずみ測定より得られたR-1試験体の荷重 ひずみ関係を示す。ここで示す結果は，繰返し荷重を数 
サイクル載荷し，波形が安定していることを確認した後 のものである. なお，下限荷重時のひずみを 0 してし ている. 図中には, 荷重と一般部4箇所（表裏面の左 右）で測定したひずみの平均值との関係も示している. 板の表裏面において測定結果にはめあいの状態に起因寸 ると考えられる大きな差が認められるが，荷重 $150 \mathrm{kN}$ 程 度までは，裏面での円孔近傍における荷重 - ひずみ関係 は一般部の荷重 - ひずみ関係とほぼ一致している。この ことは, 鋼板裏面と丸鋼が一体として挙動していること を意味している.

図-4は各試験体の上下・表裏面の4箇所で測定された 荷重 - ひずみ関係の平均である．図中には，円孔のない 平板の計算結果を破線で， $\mathrm{H}$ 試験体を対象とした線形弾 性FEM解析より得られたゲージ貼付位置の值を点線で示 している，なお，解析モデルの要素分割は後述の非線形 解析モデルと同じとしている. 図-3で示したR-1試験体 では, 鋼板表裏面で荷重 - ひずみ関係が大きく異なった ため, 初期の荷重 - ひずみ関係の傾きが円孔のない鋼板 よりも急になっている. しかし，他の3体の試験体での 傾きは，円孔のない平板と荷重 - ひずみ関係の勾配が一 致している. なお，これらの3体の試験体では，表裏 面・上下の荷重 - ひずみ関係の差は小さく, 荷重が $100 \mathrm{kN}$ までの勾配の差は最大でも $26 \%$ 以下であった。 ま た, いずれの試験体とも, 荷重が $100 \sim 150 \mathrm{kN}$ (公称応力 範囲 : 70〜 105 N/mm²) を越えると, 荷重 -ひずみ関係 の勾配が変化してH試験体モデルの解析結果と勾配に近 づいている.これは，各試験体とも荷重100～150kNで丸 鋼と円孔壁間の支圧力が減少した，才なわち接触が切れ 始めたことを意味しているものと考えられる.

\section{(2) 静ひずみ測定試験}

静ひずみ測定試験では，H-0試験体とR-0試験体を対象 として円孔の左右に貼付した 5 連ゲージを用い，長手方 向ひずみの分布より, 円孔近傍の応力集中の状況を推測 した. 試験には載荷能力 $2000 \mathrm{kN} の$ 万能試験機を用い, 試験体が破断するまで徐々に載荷した.

図-5は，鋼板と丸鋼が一体になっていると考えられる $35 \mathrm{kN} \cdot 118 \mathrm{kN}$ 載荷時, 接触が切れたと考えられる $216 \mathrm{kN}$ ・298kN載荷時のひずみ測定結果を示している. 図の縦軸は測定ひずみを公称ひずみで除したひずみ集中 係数，横軸は円孔壁からの板幅方向の距離である. また, 図中のプロットは板表裏面・左右のひずみ測定值の平均 である. 円孔壁から $2 \mathrm{~mm}$ 離れた位置に着目寸ると，H試 験体のひずみ集中係数に載荷荷重による差はほとんどな いが，R試験体では鋼板と丸鋼が一体となっていると考 えられる領域（荷重35，118kN）ではH試験体に比べて 35\%程度ひずみ集中が緩和されている. しかし, 接触が

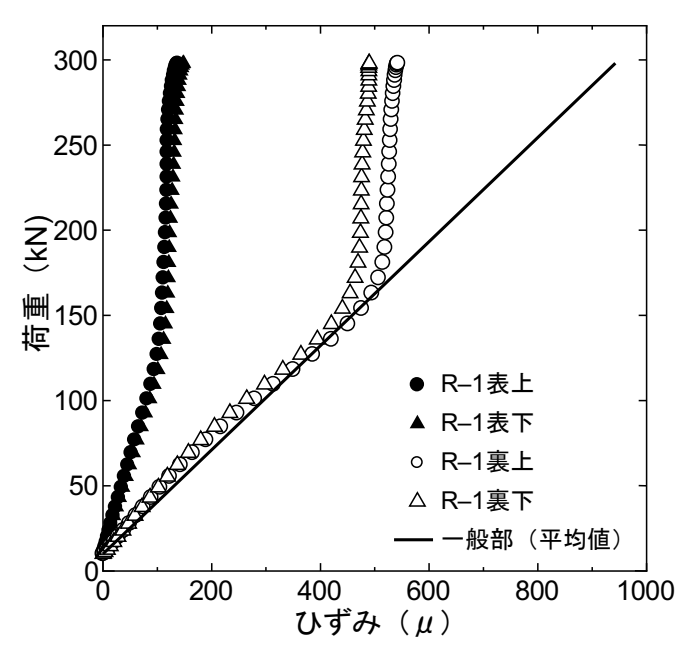

図-3 荷重-ひずみ関係（R-1 試験体）

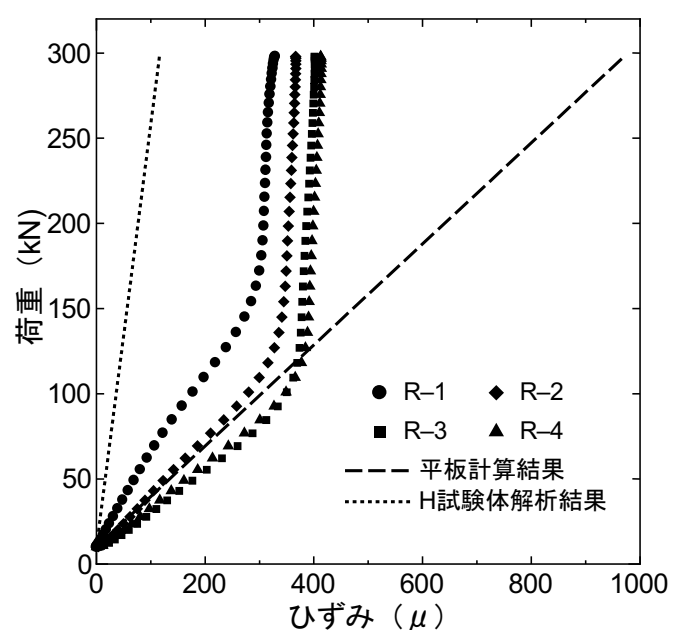

図-4 荷重一ひずみ関係 (平均值)

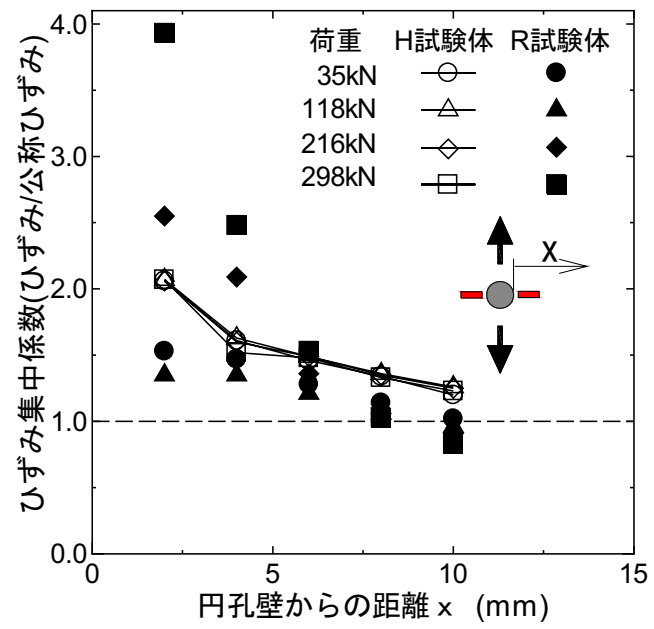

図-5 円孔近傍のひずみ集中係数の分布

切れたと考えられる領域（荷重216，298kN）では，H試 験体よりもひずみ集中が高くなっており，またその差は 荷重が大きい場合に顕著である.これは，後述の解析か らも推測されるように， $\mathrm{R}$ 試験体の円孔部近傍では冷や しばめ時に引張ひずみが導入されるために，鋼板と丸鋼 の接触が切れた後はH試験体よりも局部的に降伏しやす 
い状態にあったためと考えられる，なお， $\mathrm{H}$ 試験体とR 試験体の最大荷重はほぼ同じであり，冷やしばめが断面 全体の降伏や引張強度に与える影響は小さいと考えられ る.

\section{4. ひずみ解析}

$\mathrm{H}$ 試験体と $\mathrm{R}$ 試験体を対象とした FEM 解析を実施し た. 解析には ABAQUS ver.6.5.3を用い，材料非線形性と 幾何学的非線形性を考慮した。鋼材のヤング率は $2.06 \times 10^{5} \mathrm{~N} / \mathrm{mm}^{2}$, ポアソン比は 0.3 , 降伏応力は表- 1 に示 した值 398N/ $\mathrm{mm}^{2}$ とした。 応力 - ひずみ関係は, bilinear とし, 降伏の判定には von-Mises の降伏条件式を用い, 降伏後の応力 - ひず夕関係の傾きはヤング率の $1 / 1000$ と した．硬化則としては移動硬化則を用いた．適用した要 素は 8 節点固体要素であり, 着目寸る円孔壁近傍の要素 寸法は $1.0 \mathrm{~mm}$ 程度としている．R $\mathrm{R}$ 試験体の丸鋼と円孔壁 の境界面には面接触要素（初期隙間 0 , 摩擦係数 0 ）を 用い, 冷やしばめについては, 引張荷重載荷前に丸鋼部 に温度荷重を与えて膨張させることにより模擬した。 な お，丸鋼と円孔壁の間には摩擦力が生じると考えられる が，冷やしばめの状況等不確定要素が多いため，便宜上， 摩擦係数は 0 とした. 丸鋼部の線膨張係数は $1.2 \times 10^{-5}$ $/{ }^{\circ} \mathrm{C}$ と，温度荷重の大きさは実験で目標としたしめし ろの $0.02 \mathrm{~mm}$ と, 冷やしばめに成功した試験体で実測さ れた最小と最大のしめしろ $0.007 \mathrm{~mm}$ と $0.041 \mathrm{~mm}$ を想定 した, $72.5^{\circ} \mathrm{C}, 25.4^{\circ} \mathrm{C}, 148.6^{\circ} \mathrm{C}$ の 3 種類である. 引張荷 重は動的載荷試験と同様の荷重を 3 サイクル与えた. 荷 重増分は, ひずみ測定試験と比較する荷重を基準とし, それらの荷重間は解析ソフトが有寸る自動増分設定機能 を利用して設定した．要素分割図を図-6 に示す．解析 モデルは, 試験体の長さ方向, 幅方向, 板厚方向の対称 性を考慮した $1 / 8$ モデルである.

図-7は，解析より得た荷重 - ひずみ関係を図-4に示し た測定結果と比較したものである. 図中の解析結果は3 サイクル目のものを示している. なお，解析では引張載 荷2サイクル目以降に荷重 - ひずみ関係にヒステリシス ループはみとめられなかった。解析結果は実験結果と同 様, 鋼板と丸鋼の接触が切れた時点で荷重 - ひずみ曲線 の勾配が大きくなっている．また，実験結果は最小しめ しろと最大しめしろを想定した解析結果の間にあり，本 解析手法により冷やしばめにより丸鋼を充填した円孔を 有する鋼板のひずみ性状を概ね把握できると考えられる。 そこで，しめしろを0.001ずつ変化させてキャリブレー ションを行った結果，この解析モデルではしめしろを 0.026mmとした場合に実験結果と最もよく一致した．以 降, しめしろ0.026 mmのR試験体モデルの解析結果を用

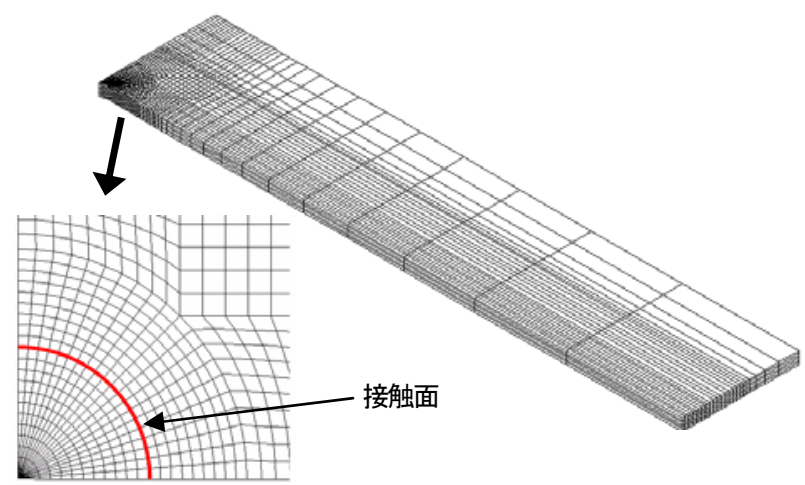

図-6 解析モデル

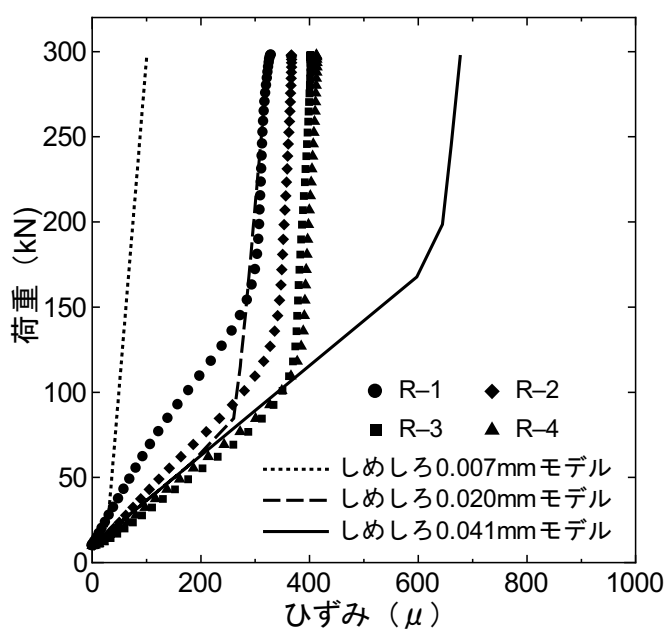

図-7 荷重-ひず夕関係の実測值と解析值の比較

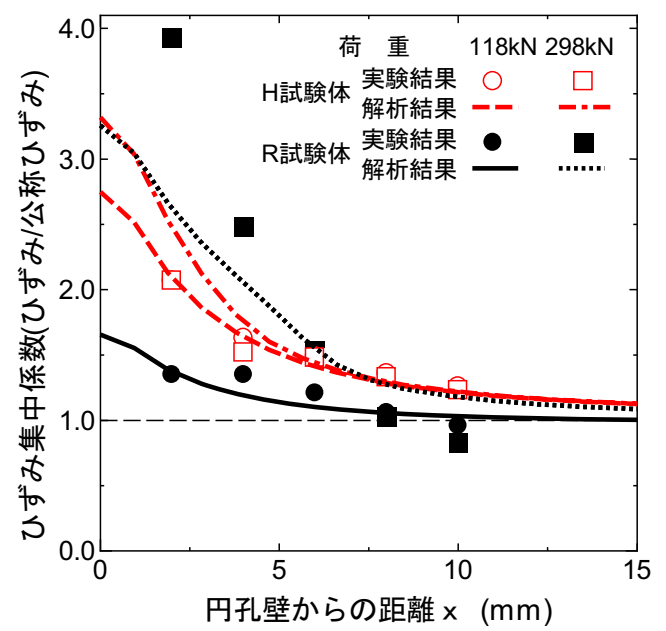

図-8 ひず夕集中係数の分布の実測值と解析值の比較

いて検討を行う.

図-8は, 解析結果（1サイクル目の荷重上昇時）を図5に示した実験結果（118kNと298kN載荷時）と比較した ものである. $298 \mathrm{kN}$ 載荷時のR試験体モデルの解析結果 は実験結果よりも小さい值となっているが，R試験体と $\mathrm{H}$ 試験体のひずみ集中係数と比較すると, 鋼板と丸鋼の 接触が切れる前はH試験体，接触が切れた後は円孔壁か ら若干離れた位置でR試験体のひずみ集中係数が大きく 


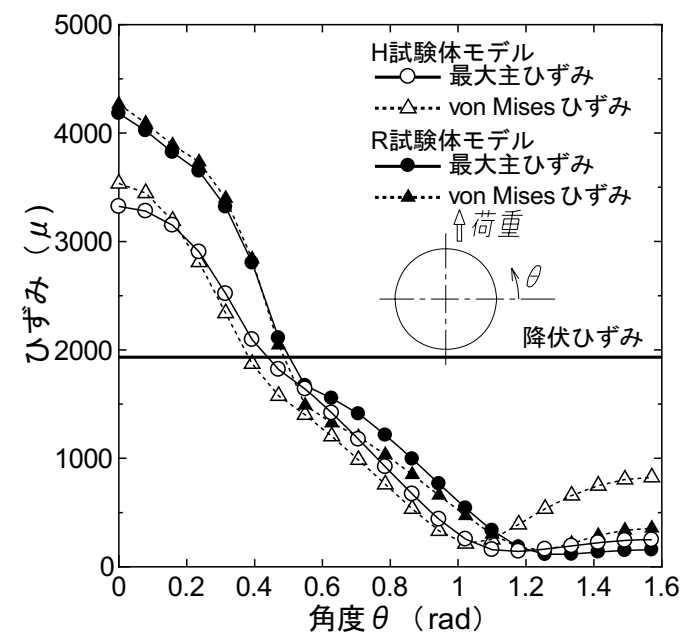

図-9 一回目 $298 \mathrm{kN}$ 載荷時の円孔壁に沿ったひずみ分布

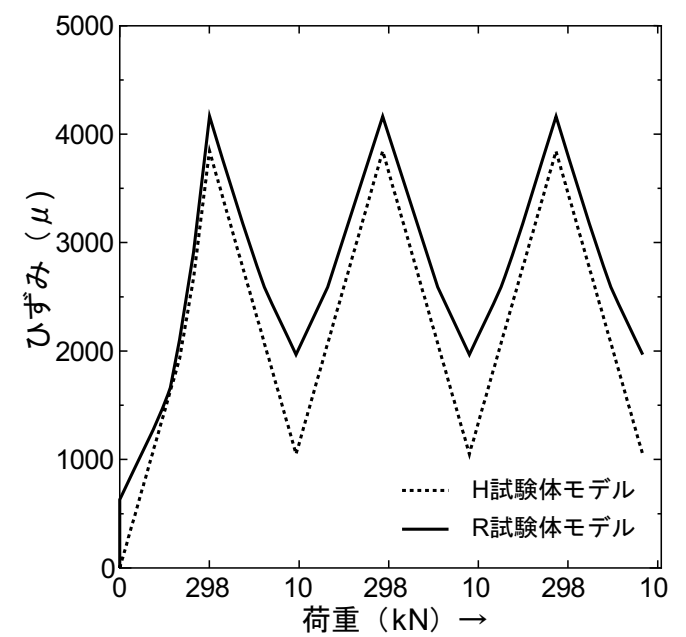

図-10 円孔壁板厚中心部での板長手方向のひずみ履歴

なるという傾向は一致している.

図-9は，一回目の $298 \mathrm{kN}$ 載荷時のR試験体モデルとH試 験体モデルの，板厚中心部の円孔壁に沿った最大主ひず みとvon Misesひずみの分布を示している．図中には降伏 ひずみも示している，最大主ひずみの值はR試験体，H 試験体共に試験体中央断面で最も大きい，また，von Misesひずみの分布をみると，R試験体モデルの試験体中 央部近傍のひずみはH試験体よりも大きく, 降伏域も広 いことが分かる.

疲労強度に対しては繰返し荷重時の応力 - ひずみ状態 に着目する必要がある. 図-10はR試験体モデルと $\mathrm{H}$ 試験 体モデルの試験体中央断面，円孔壁板厚中心部での板長 手方向のひずみ履歴である. 定常状態と考えられる三回 目の荷重載荷時の解析結果をみると, H試験体モデルと $\mathrm{R}$ 試験体モデルの最大ひずみは，それぞれ $3843 \mu, 4164 \mu$ と冷やしばめによりひずみが導入されるR試験体モデル のひずみが大きいが，疲労強度の支配因子と考えられる ひずみ範囲はH試験体モデルで $2795 \mu$ R 試験体モデルで $2197 \mu$ と，R試験体モデルの方が小さい.

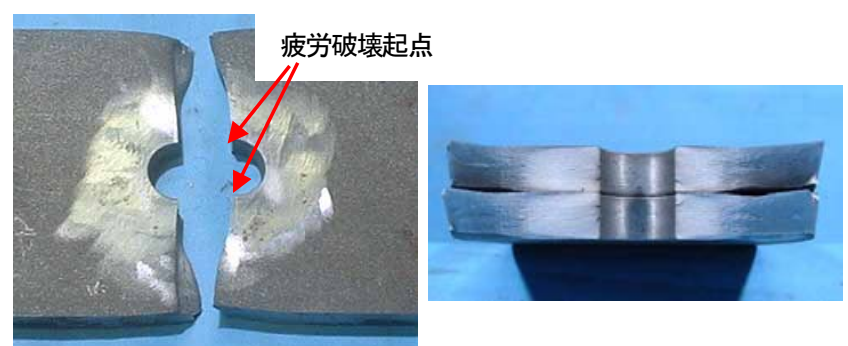

(a) $\mathrm{H}$ 試験体

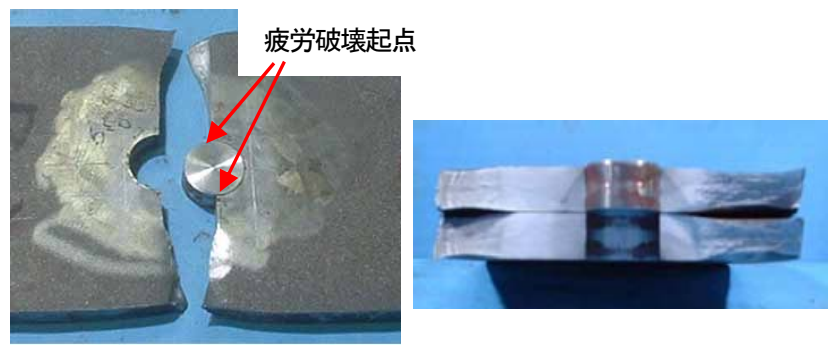

(b) R-1 試験体

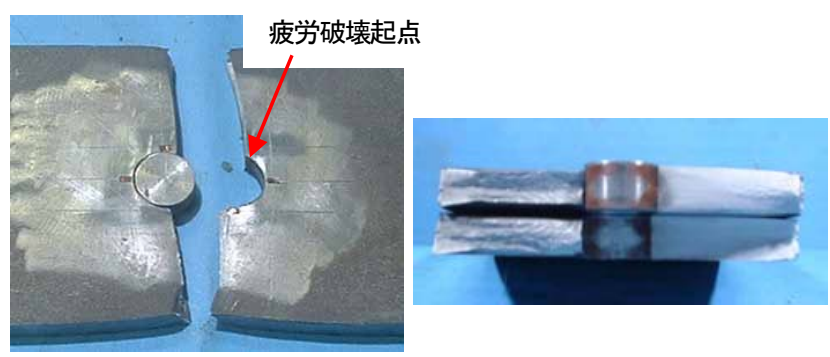

(c) R-4 試験体

写真-3 試験体の破断状況

表-3 疲労試験結果

\begin{tabular}{|c|r|r|r|}
\hline $\mathrm{H}$ 試験体 & $\begin{array}{c}\text { 疲労寿命 } \mathrm{N} \\
\left(\times 10^{4} \text { cycles }\right)\end{array}$ & R試験体 & $\begin{array}{c}\text { 疲労寿命 } \mathrm{N} \\
\left(\times 10^{4} \text { cycles }\right)\end{array}$ \\
\hline $\mathrm{H}-1$ & 22.4 & $\mathrm{R}-1$ & 133.9 \\
\hline $\mathrm{H}-2$ & 20.3 & $\mathrm{R}-2$ & 190.9 \\
\hline $\mathrm{H}-3$ & 21.2 & $\mathrm{R}-3$ & $>1000.0$ \\
\cline { 3 - 4 } & $\mathrm{R}-4$ & 166.8 \\
\cline { 3 - 4 } & & \multicolumn{2}{c}{}
\end{tabular}

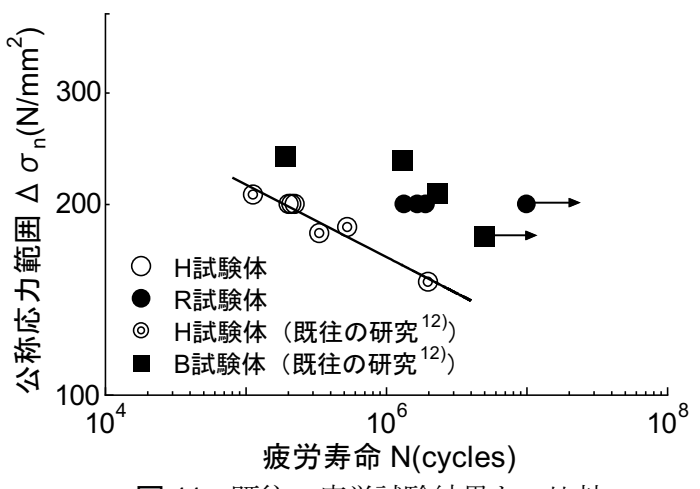

図-11 既往の疲労試験結果との比較

\section{5. 疲労試験}

疲労試験は動ひずみ計測と同じ試験機を用い，総断面 公称応力範囲を $200 \mathrm{~N} / \mathrm{mm}^{2}$ (下限荷重 $10 \mathrm{kN}$, 上限荷重 298kN）とした片振り繰り返し応力下で行った. 荷重波 形は正弦波，繰返し速度は $8 \mathrm{~Hz}$ である.

写真-3(a) (c)に試験体破断状況の一例を示す．H試験 体の疲労亀裂の起点は, すべてひずみ集中の最も高い円 
孔壁の板厚中心部近傍の試験体長手方向中心位置であつ た．またR試験体においても4体の内2体で，最大のひず み集中が確認された円孔壁の試験体長手方向中心位置か ら疲労き裂が生じた（写真(b)）。 R-4試験（写真(c)）の み，長手方向中心位置から若干離れた位置から疲労き裂 が発生した。この位置においても図-9に示すように高い ひずみ集中が生じている，なお， R試験体では板厚中心 部近傍からき裂が発生するものと板表面近傍からき裂が 発生するものがあった。

表-3に疲労試験結果の一覧を示す， R 試験体の疲労寿 命は， H試験体の疲労寿命と比べ5倍以上となっている. これは前章に示したように， R試験体の円孔壁でのひず み範囲がH試験体よりも小さくなっており，はめあいの 状態によってはひずみの差がさらに大きくなるためと考 えられる. なお， $\mathrm{R}$ 試験体の疲労寿命は，表-2に示した 最大しめしろが大きいものほど寿命が長い傾向が認めら れる.

図-11 は本研究で得られた疲労試験結果を, 円孔を高 力ボルトで締め付けた試験体（B 試験体）の疲労試験結 果 ${ }^{12)}$ と比較したものである. $\mathrm{R}$ 試験体の疲労強度は $\mathrm{B}$ 試 験体とほぼ同じである。

\section{6. まとめ}

（1）丸鋼を冷やしばめした円孔を有する平板は，ある荷 重まで円孔のない平板と同様の挙動を示す.

鋼板と丸鋼の接触が切れた後は，冷やしばめ時に導 入された引張ひずみの影響で円孔近傍の降伏域が大 きくなり, 円孔のみの場合と比較して円孔壁の最大 ひずみが大きくなるが，ひずみ範囲は小さくなる.

(2) 円孔を有する平板に丸鋼を冷やしばめすることによ り，疲労寿命の大幅な改善が期待できる.

本研究で用いた冷やしばめ試験体は円孔を高力ボル トで締め付けた場合と同程度の疲労強度を有する。
謝辞 : 本研究の遂行にあたり，研究当時，法政大学 土 木工学科の学生であった斎藤宏樹氏にご協力を頂いた. ここに記して深謝します.

\section{参考文献}

1) 永島菊三郎：力嵌めに関する研究，機械学会論文集，第 3 巻第 13 号, pp.283-289, 1937.

2) 永島菊三郎：円筒に関する塑性理論並に焼嵌め及び力嵌 めに関する計算式について（第 3 報），機械学会論文集， 第 8 巻第 31 号（第 1部）, pp.I-103-I-115, 1942.

3) 築添正, 久門輝正, 三好和寿 : 冷しばめにおける表面あ らさの影響（第 2 報，軸と円筒の冷しばめ），日本機械 学会論文集（第3部）, 39巻 323 号, pp. 2213-2222, 1973.

4) 久門輝正，三好和寿 : 冷しばめにおける真円度の影響, 日本機械学会論文集（第 3 部），39 巻 320 号, pp. 13421352, 1973.

5) Yang, G. M., Coquille, J. C., Fontaine, J.F. and Lambertin, M.: Influence of roughness on Characteristics of tight interference fit of shaft and hub, International Journal of Solids and Structures, Vol. 38, pp. 7691-7701, 2001.

6) 小林徹, 九鳥山正義, 松村昇 : 光弾性によるクランク軸の 焼ばめ応力解析，三菱重工技報，Vol.12, No.5，pp. 6-12， 1975.

7) 高橋賞, 島本聡, 野方文雄 : 接触問題の光弾性応力解析 一焼ばめによる同心・偏心軸及びキー溝を有する軸一， 非破壊検查，第 25 巻 8 号, pp.478-483， 1976.

8) 青木照子, 石田瑞穂, 島本聡, 高橋賞 : 接触圧を受ける 組合せ円板の応力拡大係数に及ぼす内外径比の影響, 非 破壊検查，第 52 巻 2 号, pp. 84-88, 2003.

9) Bu-Yu Yan: Accurate Calculation for Expansion Fit, Cryog Refrig, pp. 306-310, 1989.

10) Shatil, G. and Page, A. G.: Multiaxial Fatigue Analysis of InterferenceFit Steel Fasteners in Aluminum Al 2024-T3 Specimens, ASTM Spec. Tech. Publ., No.1417, pp. 192-208, 2003.

11) Lanciotti, A. and Polese, C.: The effect of interference-fit Fasteners on the fatigue life of central hole specimens, Fatigue \& Fract. of Eng. Mater. Struct., Vol.28, No.7,pp. 587-597, 2005.

12) 森猛 : ストップホール法をボルト締めすることによる疲 労亀裂補修効果, 構造工学論文集, Vol.35A, pp. 969-976, 1989.

(2007.4.27 受付)

\section{STRAIN PROPERTIES AND FATIGUE STRENGTH OF STEEL PLATE WITH CIRCULAR HOLE FILLED BY EXPANSION FIT OF ROUND-BAR}

\section{Daisuke UCHIDA and Takeshi MORI}

A circular hole which removes weld defect or is mistakely drilled is usually repaired by welding. This portion may have various defects. Instead of the welding, we are interested in expansion fit of the round steel bar into the hole as a repair method. This method may realize stress transmission through the hole position due to bearing-pressure.

This study aim at making clear the strain properties and fatigue strength of steel plate with circular hole filled by expansion fit steel round-bar. For this purpose, we have performed strain measuring tests, fatigue tests and stress analyses by finite element method on model specimens. 